DOI: $\underline{10.32702 / 2307-2156-2020.10 .1}$

УДК: $352.07: 37$

\title{
N. Datsii
}

Doctor of Sciences in Public Administration, Professor, Professor of the Department of economic theory, intellectual property and public administration, Polissya National University

ORCID ID: 0000-0003-0640-6426

\section{Hubar}

Master of specialty "Public management and administration" of the department of economic theory, intellectual property and public administration, Polissya National University

ORCID ID: 0000-0003-2863-143X

P. Hubar

Master of specialty "Public management and administration" of the department of economic theory, intellectual property and public administration, Polissya National University

ORCID ID: 0000-0003-2831-0169

\section{EDUCATIONAL MECHANISMS OF LOCAL GOVERNMENT DEVELOPMENT IN CONDITIONS OF SUSTAINABLE DEVELOPMENT}

\author{
H. В. Дацій, \\ д. держ. упр., профессор,
}

професор кафедри економічної теорії, інтелектуальної власності та публічного управління,

Поліський національний університет

I. С. Губар,

магістр спеціальності «Публічне управління та адміністрування» кафедри економічної теорії, інтелектуальної власності та публічного управління,

Поліський національний університет

П. М. Губар,

магістр спеціальності «Публічне управління та адміністрування» кафедри економічної теорії, інтелектуальної власності та публічного управління,

Поліський національний університет

\section{ОСВІТНІ МЕХАНІЗМИ РОЗВИТКУ МІСЦЕВОГО САМОВРЯДУВАННЯ В УМОВАХ СТАЛОГО РОЗВИТКУ}

It is determined that the relevance of local self-government is due to the fact that the level of its development at the territorial level is the main indicator of decentralization of public administration and demonopolization of the economy. The presence of an effective institution of local government ensures the rational distribution of functions, powers, responsibilities and resources at the territorial level and the formation of a qualitatively new, fairer system of relations in society, which allows to obtain a high economic and social effect.

It is proved that the system is based on the assumption that at the local level of government, it should be a balance of territorial and sectoral interests, which is possible by combining two strategies: modernization strategy, which is carried out "from above", defined at the state level, and 
the strategy of advanced development of education, which is formed as an organic part of the territorial development strategy, takes into account the target priorities and accumulated resource potential of the municipality, based on the integration of goals and resources of local society, economic entities on the territory.

It is substantiated that improving the quality and accessibility of education, for which the conditions are created at the territorial level of government, is possible only through the holistic development of municipal education systems.

It is proved that the implementation of initiatives within the framework of modernization of education requires adaptation to local conditions and the search for those options for innovation, which at the local level of government would create opportunities for the implementation of the strategy of advanced development or would not hinder it. This principle means that in order to achieve socially significant results and rational use of certain resources, it is unacceptable to make changes in the system without adopting a strategy for the development of education, associated with the strategy of sustainable development of the territory.

It is determined that the absolutization of economic factors of education development in the complex of modernization projects coming from the state level should be supplemented by strengthening the social direction of local innovations taking into account the specific characteristics and conditions of municipal education. Only in this case it will be possible to ensure the integrity and sustainability of the education system.

It is substantiated that the minimum level of inclusion is considered to be awareness of the innovations of all those whom it affects to one degree or another. Even such "passive" inclusion in the innovation process can influence a more positive general attitude of society to changes in education, establish a dialogue between all interested social and professional groups, and move on to cooperation on education development.

It is proved that the main conditions for modernization of education at the local level are the development of innovations provided by the state modernization strategy, support of educational institutions to increase the effectiveness of innovations, and provide measures to reduce risks and possible negative consequences in cases where these mandatory innovations are difficult to implement in the municipality.

Визначено, щуо актуальність місцевого самоврядування викликана тим, щзо рівень його розвитку на територіальному рівні - головний показник децентралізації публічного управління $і$ демонополізації економіки. Наявність дієвого інституту місиевої влади забезпечує ращіональне розподіл функиій, повноважень, відповідальності $i$ ресурсів на територіальному рівні та формування в суспільстві якісно нової, більш справедливої системи відносин, щуо дозволяє отримати високий економічний і соціальний ефект.

Доведено, що система будується на припущенні, щзо на місцевому рівні управління повинен бути забезпечений баланс територіальних і галузевих інтересів, який можливий при поєднанні двох стратегій: стратегії модернізації, яка проводиться «зверху», визначається на державному рівні $i$ пропонує новації в галузевих механізмах управління освітою, $i$ стратегії випереджального розвитку освіти, яка формується як органічна частина територіальної стратегї розвитку, враховує иільові пріоритети і накопичений ресурсний потенціал муніципалітету, базується на інтеграції изілей $і$ ресурсів місцевого соиіуму, суб'єктів господарської діяльності на території.

Обгрунтовано, щзо підвищення якості та доступності освіти, умови для якої створюються на територіальному рівні управління, можливо тільки шляхом цілісного розвитку муніципальних систем освіти.

Доведено, щзо реалізація ініціатив в рамках модернізації освіти вимагає адаптації до місиевих умов $i$ пошуку тих варіантів нововведень, які на місцевому рівні управління створювали б можливості для реалізаџії стратегії випереджального розвитку або не перешкоджали б ій. Такий принщип означає, щуо для досягнення соціально значущих результатів і раціонального використання визначених ресурсів неприпустимо здійснювати 
зміни в системі без прийняття стратегї розвитку освіти, пов'язаною зі стратегією сталого розвитку території.

Визначено, щзо абсолютизачія економічних факторів розвитку освіти в комплексі модернізаційних проектів, які йдуть з державного рівня, повинна бути доповнена посиленням сочіального направлення місцевих інновацій з урахуванням специифічних характеристик $i$ умов муніципальної освіти. Тільки в изьому випадку можна буде забезпечити иілісність і стійкість розвитку системи освіти.

Обгрунтовано, щзо мінімальним рівнем включення вважається інформованість про нововведення всіх, кого воно в тій чи іншій мірі зачіпає. Навіть таке «пасивне» включення в інноваційний процес здатне вплинути на більш позитивне загальне ставлення соиіуму до змін у сфері освіти, налагодити діалог між усіма зацікавленими соціальними і професійними групами, перейти в подальшому до співпраці по питанням розвитку освіти.

Доведено, щуо основними умовами для модернізації освіти на місцевому рівні є освоєння тих новачій, які передбачені державною стратегією модернізачії, підтримка освітніх установ, щзоб підвищити ефективність нововведень, і передбачити заходи щзодо зниження ризиків $i$ можливих негативних наслідків у випадках, коли изі обов'язкові новації виявляються важко реалізованими в умовах муніщчипалітету.

Key words: information openness; development mechanisms; local self-government; municipality; education development; sustainable development; strategic reasonableness; territorial system; management.

Ключові слова: інформаційна відкритість; механізми розвитку; місиеве самоврядування; мунічипалітет; розвиток освіти; сталий розвиток; стратегічна обтрунтованість; територіальна система; управління.

The purpose of the article is to define as a mission to create conditions for sustainable development of the municipal education system; explore innovations in the education system at the local level; substantiate the priority of social goals and socially oriented innovations within the framework of municipal strategies for educational development; determine the need and completeness of resources for innovation to manage the development of education.

Formulation of the problem.

The traditional underestimation of local self-government by the authorities has left a certain imprint on public administration. Thus, in the field of management not only the economy but also the development of territories, as a rule, the object of attention is not the pyramid, but the vertical of management. Experience shows that the management pyramid, which is based on local self-government, is more acceptable in relation to the territory. The use of a pyramidal structure gives the power system greater stability, makes it more reliable and efficient. However, the pyramid form of the system acquires only if the country has authorized local governments, which together are the main institution of civil society. The absence of such means that the country has not created the conditions for the formation of a given society.

The relevance of local self-government is due to the fact that the level of its development at the territorial level is the main indicator of decentralization of public administration and demonopolization of the economy. The presence of an effective institution of local government ensures the rational distribution of functions, powers, responsibilities and resources at the territorial level and the formation of a qualitatively new, fairer system of relations in society, which allows to obtain a high economic and social effect. The process of modernization of education is an integral part of socio-economic modernization of the country, which defined the system-forming principles of the new organizational and economic model of education: reduction of state presence, formation of the market of educational services and competitive environment in education.

Analysis of recent research and publications.

Problems of development of local self-government, municipal and educational management are considered in many scientific works (L.V. Batchenko, V.V. Burega, V.G. Gamayunova, V.V. Dorofienko, I.M. Drobiazko, E.M. Korotkov, V.V. Kryzhko, V.M. Lobas, V.I. Lugovoi, T.G. Morozova, E.M. Pavlyutenkov, S.F. Povazhny, V.O. Romanov, P.G. Tsitsyn, O.I. Chernysh, S.K. Khadzhiradeva and others) and are mainly devoted to the development of theoretical foundations of municipal management, economically profitable projects in the system of local government, management of educational services. 


\section{Presentation of the main material.}

Under the current socio-economic conditions, the values of education management (which are formulated as a result as its mission) are several key provisions:

- the municipal education system should be considered as an integral part of the territorial socio-economic complex, and the development of education should be carried out in conjunction with the goals and objectives of municipal development;

- the development of the municipal education system should ensure the implementation of state policy in the field of education;

- the integrity and sustainability of the development of the entire education system must be ensured;

- the development of education should be carried out in the direction of strengthening its social function;

- in the current conditions must be ensured the stabilization of conditions and processes in the education system as a counterweight to instability in connection with the socio-economic modernization [6, p.225].

The system is based on the assumption that the local government should ensure a balance of territorial and sectoral interests, which is possible by combining two strategies: modernization strategy, which is carried out "from above", defined at the state level and offers innovations in sectoral mechanisms of education management. advanced development of education, which is formed as an organic part of the territorial development strategy, takes into account the target priorities and accumulated resource potential of the municipality, based on the integration of goals and resources of local society, economic entities in the territory [5, p.125].

When combining the two mega-strategies, the development of education is carried out by supplementing and compensating for regional measures to modernize education with a set of local horizontally integrated mechanisms for the support and development of education.

Thus, the mission is to create conditions for sustainable development of the municipal education system as part of the territorial socio-economic complex, strengthening the social function of education through a combination of strategies "modernization" and "advanced development".

The question of the principles of management of sustainable development of educational systems can not be solved in isolation from the initial provisions of management theory, developed in the early XX century. It was at that time that many principles of governance were formulated, which have not lost their significance to this day. The founders of scientific management FW Taylor, G. Emerson, A. Fayol identified as the most important principles such as division of labor and specialization, single leadership, division of powers and their delegation, discipline and responsibility, fair remuneration for work, staff motivation and others.

Later, in connection with changes in management concepts, shifting the emphasis on product quality in conditions of increasing competition, high dynamics of economic life, were added such principles as management flexibility, which allows you to restructure the management system depending on changing conditions and objectives; mobility, as the ability to restructure at the required speed, purposefulness, strategic approach, systems approach, quality management as a cross-cutting principle of management decisions, etc.

In the education management system in the last 20 years, the principles of public administration have become well-known, which recognizes the right to participate in management decisions of all participants in the educational process and representatives of interested social groups; the principle of regionalization, according to which there is a gradual transfer of powers to manage education from the center to the field, as well as to municipalities; the principle of division of powers between the levels of government of the unified education system [7, p.6].

The system presents two groups of principles, which can be called basic and specific, due to the need to solve specific management tasks, taking into account the level of management, formulated management concepts and management mission.

The basic principles include those that reflect modern scientific ideas about the effective organization of management: systematic management activities; hierarchy of management system; functional completeness; completeness of the management cycle; specialization of management activities; democracy in decision-making; distribution of powers and their delegation; participatory management, which increases the effectiveness of management decisions through training of performers; flexibility of structures and management mechanisms; mobility of the management system; the adequacy of the complexity of the management system of the complexity of the managed object.

Specific principles are due to the peculiarities of the tasks of managing the development of education at the municipal level.

Balance of territorial and sectoral interests. Currently, the municipal level of government implements sectoral policy in the field of education. However, local education authorities are created by local governments to exercise their responsibilities in the field of education, accountable to them, is an important link in the structure of mechanisms of local social policy, which requires a more balanced educational policy that reflects the specific socio-cultural, demographic, economic situation and related to the overall development strategy of the municipality [3,p.60].

Ensuring the integrity of the development of the local education system. The course and results of the current stage of modernization of education show that the selection, selection and support of leaders, the focus on creating a competitive environment as the guiding principles of modernization of modern education focus on the impasse and do not ensure the development of the entire education system. The assumption that weak, "non-competitive" educational institutions will either disappear or improve their performance in competition with the strongest seems naive and does not meet the goals, objectives, methods of organizing general education, constitutional guarantees of its accessibility [1, 
p.149]. Improving the quality and accessibility of general education, the conditions for which are created at the municipal level of government, is possible only through the holistic development of municipal education systems.

Strategic soundness of innovations. A combination of modernization strategy and advanced development strategy is needed. Any innovation in the education system at the local level should be considered only in the logic of these strategies, developed and specific to the conditions of the territory. Even the implementation of initiatives in the framework of modernization of education requires adaptation to local conditions and the search for those options for innovations that at the municipal level of government would create opportunities for the implementation of the strategy of advanced development or would not hinder it. This principle means that in order to achieve socially significant results and rational use of certain resources, it is unacceptable to make changes in the system without adopting a strategy for the development of education, associated with the strategy of sustainable development of the territory.

The principle of additionality. In social practice, in particular in the practice of management, the principle of additionality allows us to take into account the dialectic of social phenomena, especially important for understanding the nature and conditions of their development. According to this principle, the management system must create conditions for diversity, for the manifestation, coexistence and interaction of opposing, mutually exclusive entities (for example, for economic and social development results, for "market" and "non-market" instruments for regulating economic activity). the object of management is preserved and developed in its entirety [4, p.107].

The territorial system of education (being a socio-economic system) cannot develop sustainably if only new economic mechanisms aimed at improving economically independent educational institutions are implemented. Absolutization of economic factors of education development in the complex of modernization projects coming from the state level should be supplemented by strengthening the social direction of local innovations, taking into account the specific characteristics and conditions of municipal education. Only in this case it will be possible to ensure the integrity and sustainability of the education system.

Social orientation of development. The priority of social goals and socially oriented innovations within the framework of municipal strategies for the development of education is a logical continuation and a certain concretization of the principle of additionality. This principle will correct the skew that has developed at this stage of modernization of education as a state initiative. Social orientation and pedagogical expediency should become priority criteria for selection of specific innovative projects at the territorial level [2].

This principle also implies the minimization of social risks from innovations in education. This aspect of social orientation indicates that the selection of innovations should be a mandatory condition for the assessment of social risks, which is not currently conducted. Minimization of social risks acts as a criterion for the selection of their own innovative projects, as well as an impetus for the development of the necessary measures for the development of "coming down from above" innovations.

Necessary and sufficient resources for innovation. This principle is revealed in two aspects that are equally important for the management of educational development.

First, it is about the realism of the chosen development goals, which is provided by the availability of opportunities to achieve them. Every innovative project must have the necessary and sufficient resource base. Lack of resources leads to an extension of project implementation time, and with severe time constraints to a decrease in the quality of results or failure to achieve them. The specifics of the current stage of modernization of education is that there is a clear contradiction between the expectation of systemic positive effects of the proposed innovations and the implementation of electoral resource (primarily financial) support for innovation, is allocated on a competitive basis to individual regions, territories, educational institutions.

To achieve systemic results in the development of education at the municipal level, ensuring the integrity and sustainability of development, maintaining a favorable innovation climate, positive motivation of the teaching community and local society to innovate, it is essential to make only those changes that are provided with resources.

Secondly, the adoption of the theory of sustainable development as a conceptual basis means that innovations will not be a condition for sustainable development of the system if they are provided only by external resources or lead to the depletion of critical internal development resources. The necessary and sufficient completeness of the resource base should be considered as a general, aggregate development potential, which provides all types and kinds of resources that are important in the context of sustainable development.

Information openness. The development of various kinds of innovations, which forms the basis of managed development, inevitably causes reliance on change. In the theory of innovation management it is proved that this resistance can be reduced or prevented by special measures to involve all stakeholders in the development and implementation of new ones. The minimum level of inclusion is considered to be awareness of the innovations of all those whom it affects in one way or another. Even such "passive" involvement in the innovation process can influence a more positive general attitude of society to changes in education, establish a dialogue between all interested social and professional groups, and move on to cooperation on educational development. Information openness is also a key condition for obtaining adequate feedback, without which it is impossible to ensure effective management.

Thus, the main conditions for the modernization of education at the municipal level are the development of those innovations that are provided by the state modernization strategy, support of educational institutions to increase innovation, and provide measures to reduce risks and possible negative consequences in cases where these mandatory innovations are difficult to implement in the municipality.

Part of a favorable innovation environment is the innovation culture, which consists, in turn, of skills of social design of innovations with the involvement of all stakeholders and groups, especially independent expertise of 
innovation projects - professional and public, skills to overcome and prevent resistance to change, teamwork skills, etc. .e. In practice, the choice of elements of the innovation environment in the formation of development goals depends on the competence of the management body, the general socio-cultural conditions of the municipality.

When forming its own strategy for the development of education, each municipality will have such sub-goals, which are determined by the results of strategic analysis, awareness of their strategic advantages, accumulated resource potential, and show by what actions, means achievable in these conditions.

\section{Conclusions.}

To manage the sustainable development of the territorial education system as part of the socio-economic complex, address strategic development of education, develop targeted education development programs, it is necessary to create collegial interagency structures within local administrations and special deputy commissions with decisionmaking powers. development of the whole territory. In addition, to achieve the goals of advanced development, the model provides for maximum diversity of collegial governing bodies, horizontally integrated organizational forms of activity through the creation of various temporary target structures based on design and product management schemes with mandatory implementation of the participatory principle, that is the inclusion of representatives of interested social groups in these schemes.

At the same time, to strengthen the flexibility and mobility of management, strengthen horizontal links in the process of addressing the modernization of education, it is conceptually important to abandon the linear-functional management structures in its purest form and use more flexible organizational schemes even within full-time education authorities. For the purposes of strategic development, the following are proposed, first of all: municipal strategic teams, coordination councils for social development, matrix structures within local government and education management body, cluster project groups and managers, coordination councils, inter-municipal program management bodies, various formal and informal network structures, public expert groups and other forms of collegial implementation of management decisions.

\section{References.}

1. Andreev, A.V. (2015), "The sphere of education as an object of public administration", Naukovyy visnyk Dnipropetrovs 'koho derzhavnoho universytetu vnutrishnikh sprav, vol. 3, pp. 146-151.

2. Andresyuk, B.P. (2017), Mistseve samovryaduvannya v suchasniy Ukrayini: problemy i perspektyvy [Local self-government in modern Ukraine: problems and prospects], Stylos, Kyiv, Ukraine.

3. Vasyltsiv, T.H. and Boiko, V.V. (2015), "The development of rural areas as a strategic priority for strengthening the country's economic security”, Stratehichni prioritety, vol. 2(35), pp. 58-62.

4. Kravchenko, V.V. Pittsyk, M.V. and Saliy, I.M. (2018), Osnovy munitsypal'noho menedzhmentu: navchal'nyy posibnyk [Fundamentals of municipal management], Atika-N, Kyiv, Ukraine.

5. Chernyatina, V.A. (2017), "State regulation of sustainable development of rural areas in Ukraine", Derzhavne upravlinnya ta mistseve samovryaduvannya, vol. 3 (34), pp. 122-127.

6. Shchokin, R.G. (2018), "Public administration in the field of education: approaches to the formation of the concept", Pravo i suspil'stvo, pp. 224-230.

7. Yagupov, V.V. and Svistun, V.I. (2017), "Competence approach to the training of specialists in the system of higher education”, Naukovi zapysky NaUKMA. Seriya 'Pedahohichni, psykholohichni nauky ta sotsial'na robota, vol. 71, pp. 3-8.

Стаття надійшла до редакції 20.10.2020 p. 